\title{
Purification and Characterization of an Extracellular Protease from Bacillus subtilis EAG-2 Strain Isolated from Ornamental Plant Nursery
}

\author{
AFIA GHAFOOR* and SHAHIDA HASNAIN \\ Department of Microbiology and Molecular Genetics, Quaid-e-Azam Campus \\ University of the Punjab, Lahore, Pakistan
}

Received 12 August 2009, revised 7 April 2010, accepted 8 April 2010

\begin{abstract}
Bacillus subtilis EAG-2 strain isolated from an ornamental plant nursery produced a highly active extracellular protease. It was purified to apparent homogeneity by successive purification steps. The SDS-gel of purified protease revealed a single band of $27 \mathrm{KDa}$ on $10 \%$ polyacrylamide gel. Proteolytic activity was confirmed by using two different zymographic methods. Interestingly, the enzyme showed two clear activity bands in both cases. The optimum proteolysis for this protease was observed at $\mathrm{pH} 8.5$ and $65^{\circ} \mathrm{C}$. The enzyme was highly stable up to $80 \%$ after $30-50^{\circ} \mathrm{C}$ for 60 minutes. It also remained stable at $\mathrm{pH} 6.5-9.0$ after 4 hours of incubation at $37^{\circ} \mathrm{C}$. Its activity was reduced to $16 \%$ and $25 \%$ by PMSF and APMSF which indicates its relation to serine proteases. An increase in activity was noticed in the presence of $\mathrm{Ca}^{+2}, \mathrm{Zn}^{+2}$ and $\mathrm{Ba}^{+2}$. On the other hand, it worked effectively with different natural substrates. Hence EAG-2 protease might be a useful contribution to the enzyme industry in Pakistan based upon its distinctive properties.
\end{abstract}

Ke y words: Bacillus subtilis, protease activity, serine protease, zymography

\section{Introduction}

Proteases belong to the class of enzymes which have been most extensively studied by scientists from various aspects (Beg and Gupta, 2003; Takami et al., 1989). The reason is their increased hourly consumption in various industries all around the world. Proteases are degradative enzymes which catalyze the total hydrolysis of proteins. They are grossly divided into two major groups - exopeptidases and endopeptidases depending upon their site of action. Based upon functional group at the active site, proteases are further classified into four prominent groups, i.e., serine protease, aspartic proteases, cysteine proteases, and metalloproteases (Beynon and Bond, 1989). Purification of proteases to homogeneity is a prerequisite to study their mechanism of action and behavior. A number of chromatographic techniques have been used to purify proteases (Adinarayana et al., 2003; Chakrabarti et al., 2000; Rawlings and Barrett, 1993) and many proteases from Bacillus species have been purified (Kang et al., 2001; Kim et al., 2001; Kobayashi et al., 1996). However, much less work has been done on proteases from this perspective in Pakistan.
The present work is based upon an extracellular protease isolated from a previously reported Bacillus subtilis EAG-2 strain. The aim of current study was to characterize this highly productive strain and to find its commercial potential, which might prove beneficial for the emerging enzyme industry in south Asian region as well as a useful addition to the existing enzyme world. Small scale experiments indicated that this enzyme exhibits a very high proteolytic activity in cell free supernatant. So we aimed to purify this specific protease. A combination of purification steps have been used including ammonium sulfate precipitation, ultrafiltration, DEAE-Sepharose chromatography and gel filtration chromatography.

\section{Experimental}

\section{Materials and Methods}

For protease production cells (Bacillus subtilis EAG-2) were grown using the same medium and culture conditions as described previously (Ghafoor and Hasnain, 2009).

* Corresponding author: A Ghafoor, Department of Microbiology and Molecular Genetics, Quaid-e-Azam Campus, University of the Punjab, Lahore. 54590, Pakistan; phone: (+92) 42 9231238; fax: (+92) 42 9230481; e-mail: afia_ghafoor@yahoo.com 
Enzyme purification. The entire purification procedure was performed at $4^{\circ} \mathrm{C}$, unless otherwise specified. A 36 hour old fermented culture was centrifuged to obtain cell free enzyme solution at $(16000 \times \mathrm{g})$ for 40 minutes. The cell pellet was discarded and supernatant was passed through $0.8 \mu \mathrm{m}$ filter (Millipore, UK). The enzyme extract was then subjected to ammonium sulfate cut from $30-80 \%$ saturation. Final precipitates were allowed to settle overnight at $4{ }^{\circ} \mathrm{C}$. Precipitates were then collected by ultracentrifugation at $(30,000 \times \mathrm{g})$ for 40 minutes. Protein pellet so formed was then dissolved in a small aliquot of $20 \mathrm{mM}$ tris buffer, $\mathrm{pH}$ 8.0. It was further dialyzed against the same buffer overnight with four buffer changes. EAG-2 dialysate was concentrated by using membrane of $3 \mathrm{KDa}$ (Amicon-Ultracel) at 4,000 rpm for 20-25 minutes at $2^{\circ} \mathrm{C}$. For further purification sample was loaded onto a DEAE-Sepharose Fast Flow column $(1.6 \times 2.5 \mathrm{~cm})$. The column was first washed with analytical grade water followed by equilibration with buffer A ( $20 \mathrm{mM}$ Tris, $\mathrm{pH}$ 8.0). Protein was eluted by using buffer B (20 mM Tris, $0.5 \mathrm{M} \mathrm{NaCl})$. Each $1 \mathrm{ml}$ fraction was collected over linear salt gradient for $40 \mathrm{ml}$ and measured for protein content at $280 \mathrm{~nm}$. Active fractions were then pooled and desalted via a PD-10 column (Amersham).

Activity assay and total protein. The total protein content of each purification step was determined by bicinchonic acid assay (BCA, Sigma, USA) with bovine serum albumin as standard. Enzyme activity was checked by modified Kunitz method (1947).

SDS-PAGE Electrophoresis. 10\% SDS gel was prepared according to Laemmli (1970). A sample aliquot was prepared by mixing $10 \mu \mathrm{l}$ of protein with $30 \mu \mathrm{l}$ of sample buffer $(62.5 \mathrm{mM}$ Tris- $\mathrm{HCl}, 2 \%$ SDS, $10 \%$ glycerol $\mathrm{pH} 6.8$ ) containing $100 \mathrm{mM}$ DTT. Samples were heat denatured for $3-5 \mathrm{~min}$ at $95^{\circ} \mathrm{C}$. Molecular weight was estimated by using phosphorylase $b$, bovine serum albumin, egg albumin, carbonic anhydrase, isomerase and lysozyme as standards.

Zymography. Method 1: Activity gel was prepared according to the method of Schmidt et al. (1988) with some modifications. A $10 \%$ Polyacrylamide gel was co-polymerized with $1 \%$ casein. The samples were applied in non-reducing Laemmli buffer without denaturation and run at $100 \mathrm{~V}$. The gel was rinsed twice in $2.5 \%$ Triton-X-100 for $30 \mathrm{~min}$, to remove SDS, and was incubated in $50 \mathrm{mM}$ Tris-HCl buffer ( $\mathrm{pH} \mathrm{8.0)} \mathrm{for}$ $1 \mathrm{~h}$ at $37^{\circ} \mathrm{C}$. The gel was stained in $0.5 \%$ Coomassie brilliant blue R-250 for 30 min followed by destaining in a solution containing methanol, acetic acid, water in ratio 50:10:40.

Method 2: A 10\% polyacrylamide gel was prepared according to Laemmli without SDS in sample buffer under non reducing conditions. Electrophoresis was performed at 100 volts in Tris-Glycine buffer
( $\mathrm{pH}$ 8.8). Gel was then transferred to $1 \%$ casein-agar plate and incubated for 35 minutes at $37^{\circ} \mathrm{C}$ in the presence of $50 \mathrm{mM}$ tris buffer $\mathrm{pH} 8.5$. Following incubation, the gel was removed and plate was stained with Coomassie Blue G-250 to visualize activity zones.

Physico-chemical characters of purified protease. Maximum catalytic activity was studied by incubating the enzyme with $1 \%$ casein as substrate. The enzyme was incubated over a $\mathrm{pH}$ range from $6-10$ at $37^{\circ} \mathrm{C}$ by using $50 \mathrm{mM}$ sodium phosphate buffer for pH 6.0-8.0; Tris-HCl buffer for 8.0-9.0 and Glycine$\mathrm{NaOH}$ buffer for $\mathrm{pH} 9.0-11.0$. The optimum temperature for activity was determined by incubating enzyme at $30-90^{\circ} \mathrm{C}$ at $\mathrm{pH} 8.5$. The $\mathrm{pH}$ stability profile was determined by pre-incubation of enzyme in buffer systems at from $6.0-11.0$ for 4 hours at $37^{\circ} \mathrm{C}$. Aliquots were withdrawn and residual proteolytic activity was measured. Thermal stability enzyme was measured by pre-incubating at $\mathrm{pH} 8.5$ for $10-60 \mathrm{~min}$ utes at $30^{\circ}, 35^{\circ}, 40^{\circ}, 45^{\circ}, 50^{\circ}, 55^{\circ}, 60^{\circ}, 65^{\circ}$ and $70^{\circ} \mathrm{C}$. Non-heated enzyme was considered as control (100\%).

Effect of metals and inhibitors. Enzyme was coincubated with metals $\left(\mathrm{Ca}^{+2}, \mathrm{Mg}^{+2}, \mathrm{Co}^{+2}, \mathrm{Fe}^{+3}, \mathrm{Na}^{+}\right.$, $\left.\mathrm{Zn}^{+2}, \mathrm{Cu}^{+2}, \mathrm{Mn}^{+2}, \mathrm{Ni}^{+2}, \mathrm{Ba}^{+2}\right)$ at $5 \mathrm{mM}$ conc. The inhibitors used in the study included iodoacetamide, APMSF, PMSF, pepstatin, leupeptin, EGTA an EDTA. Commercially available Alcalase and Esperase were also used for comparison.

Enzyme-substrate relationship. To study timecourse activity relationship Different substrates including casein, ovalbumin, gelatin, chicken albumin and hemoglobin were used. $1 \%$ Buffered solution of each substrate was prepared and incubated with purified enzyme over a time range of 10-70 minutes. The rate of proteolysis was measured by Kunitz method in triplicate for each time interval.

\section{Results}

Protease purification. Initially, the strain was highly active on Milk agar plates. Caseinase activity of EAG-2 was further confirmed by growing the organism on Casein-agar plates concentration ranging from $0.3-1 \%$ (Fig. 1a). Results at each step of purification are summarized in Table I. Maximum protease activity was precipitated in fractions from 65-80\% ammonium sulfate saturation (Fig. 1b). A large proportion of unbound protein was detected as a dominant peak during first few minutes after loading sample in flow-through from the column. Bound proteins were eluted from the column over a linear $\mathrm{NaCl}$ gradient of $0-1.0 \mathrm{M}$. Maximum caseolytic activity was measured in fractions pooled from DEAE-Sepharose FF column with the specific activity of $12,456 \mathrm{Umg}^{-1}$. This step defines the puri- 
Table I

Purification profile of EAG-2 protease

\begin{tabular}{|l|c|c|c|c|c|}
\hline \multicolumn{1}{|c|}{ Step } & $\begin{array}{c}\text { Total protein } \\
(\mathrm{mg})\end{array}$ & $\begin{array}{c}\text { Total activity } \\
(\mathrm{U})\end{array}$ & $\begin{array}{c}\text { Specific activity } \\
\left(\mathrm{U} \mathrm{mg}^{-1}\right)\end{array}$ & $\begin{array}{c}\text { Purification } \\
\text { Yield (\%) }\end{array}$ & $\begin{array}{c}\text { Purification } \\
\text { fold }\end{array}$ \\
\hline Crude enzyme & 178 & 198543 & 1115.4 & 100 & 1.0 \\
\hline$\left(\mathrm{NH}_{4} \mathrm{SO}_{4}\right)$ precipitation, 80\% saturation & 64 & 94540 & 1477.1 & 47.6 & 1.3 \\
\hline DEAE-cellulose eluate & 4.6 & 57300 & 12456 & 29 & 11.0 \\
\hline
\end{tabular}

fication of EAG-2 protease to homogeneity level. While the over all yield of purified enzyme was $29 \%$ and it was purified up to 11-fold. Purified enzyme showed a single band of $27 \mathrm{KDa}$ on SDS gel.

Catalytic optimization of EAG-2. Purified protease was maximally active at $\mathrm{pH} 8.5$ against casein as substrate (Fig. 2). The enzyme was thermally active between $30-70^{\circ} \mathrm{C}$ with an optimum at $65^{\circ} \mathrm{C}$ while a sharp decline in activity was observed beyond $70^{\circ} \mathrm{C}$. The purified enzyme was highly stable within $\mathrm{pH}$ range $6-9$. The activity reduced $30-45 \%$ from $\mathrm{pH} 10-11$. The enzyme was thermally stable from $30-55^{\circ} \mathrm{C}$ dur-
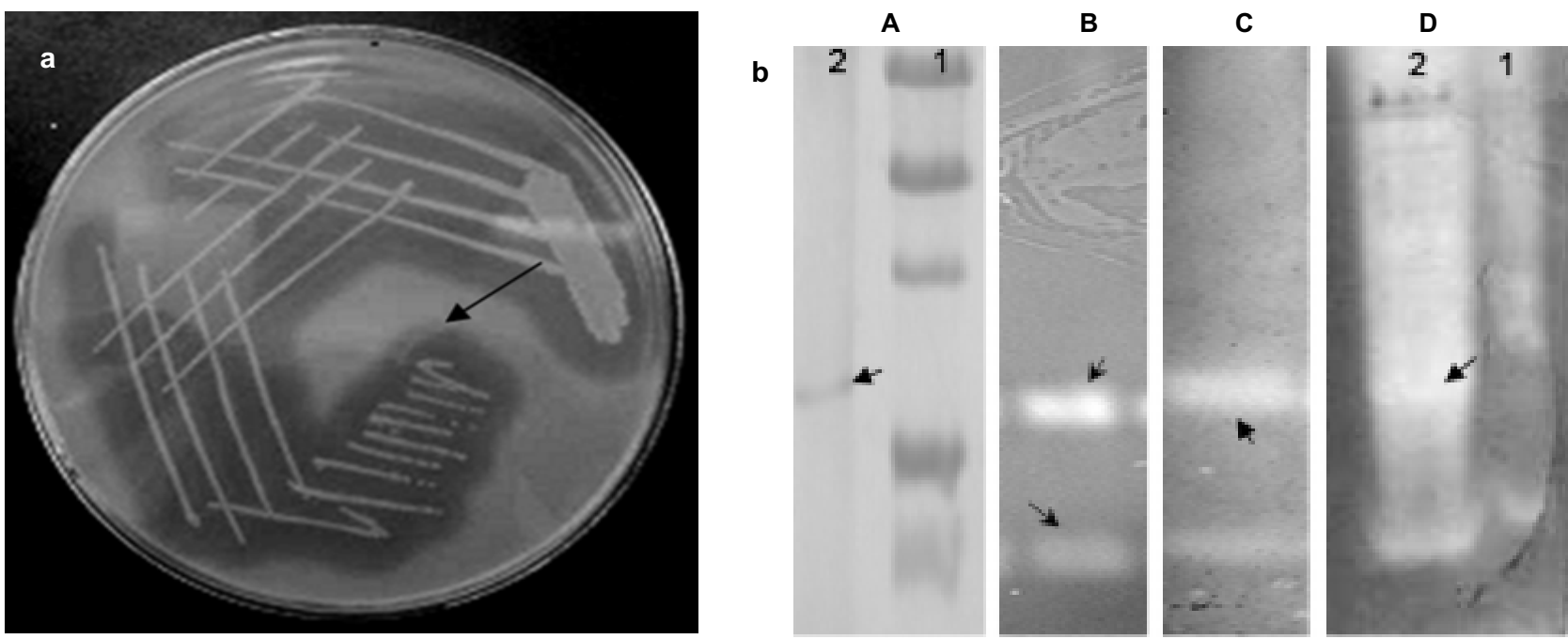

Fig. 1. Caseolytic activity of EAG-2 strain; (a) proteolytic zones around EAG-2 bacterial growth on 1\% casein; (b) electrophoresis of purified EAG-2 protease.

A: $10 \%$ SDS gel of purified EAG-protease; lane 1: Molecular wt markers (bovine serum albumin, $66.2 \mathrm{kDa}$; Egg albumin, $45 \mathrm{kDa}$; gluceraldehyde dehydrogenase $36 \mathrm{kDa}$; tripsinogen $24 \mathrm{kDa}$; trypsin inhibitor $20 \mathrm{kDa}$ ), lane 2: purified EAG-2 protease; B: Zymogram (method-1); C: Zymogram (method-2); D: Zymogram (lane 1: crude enzyme, lane 2: precipitated sample).

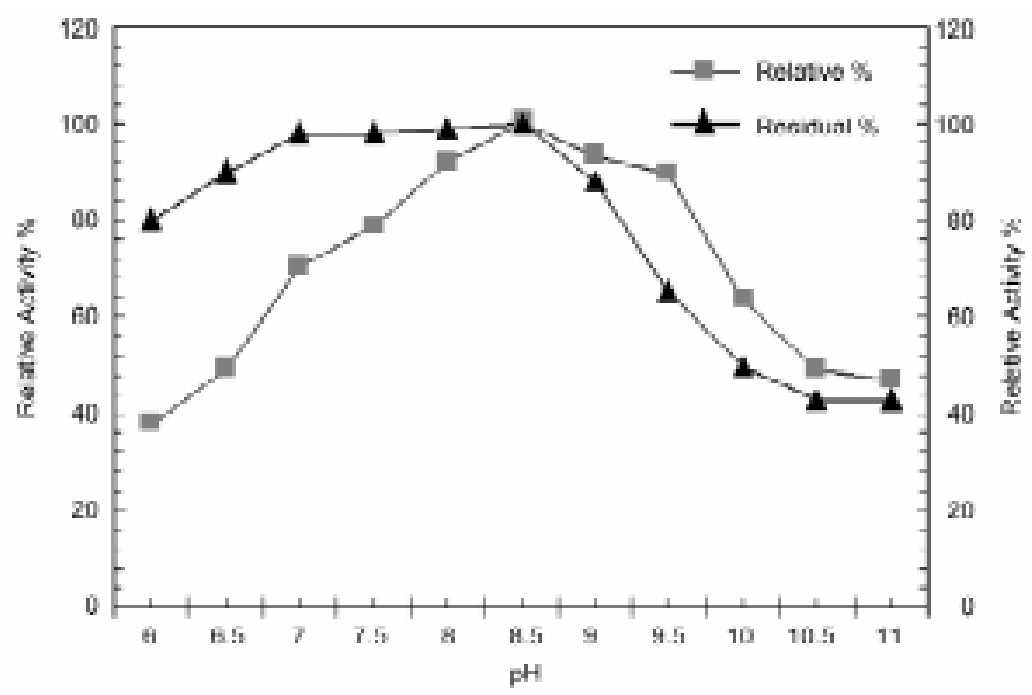

Fig. 2. pH optimization of purified EAG-2 protease. 


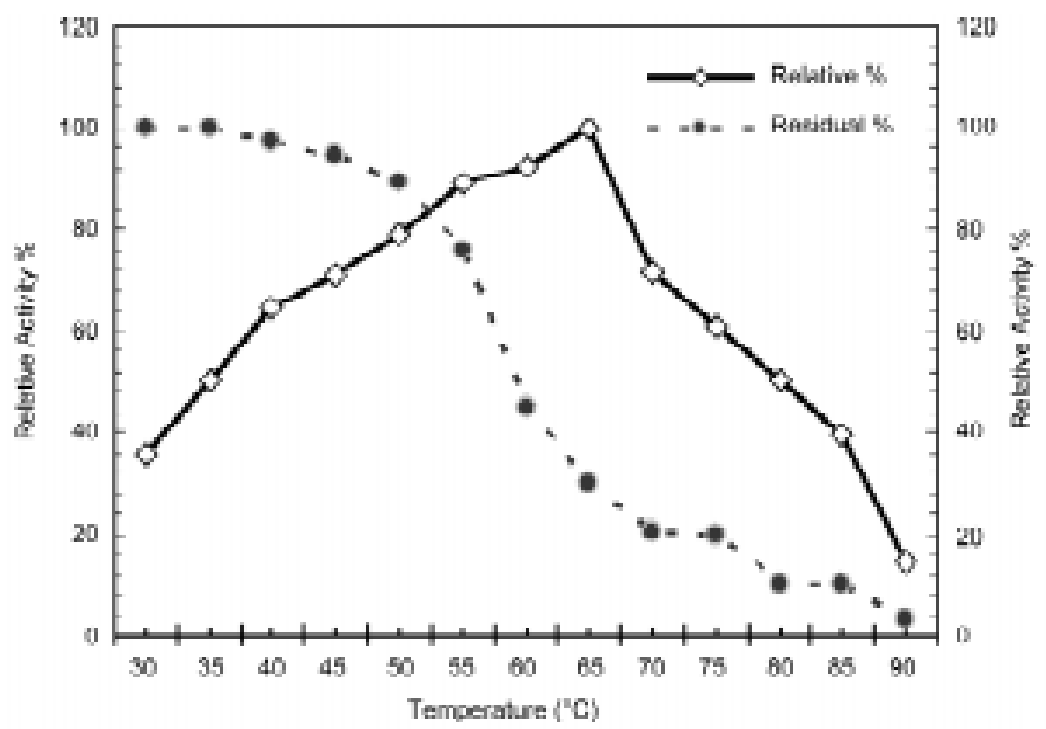

Fig. 3. Temperature optimization of purified EAG-2 protease

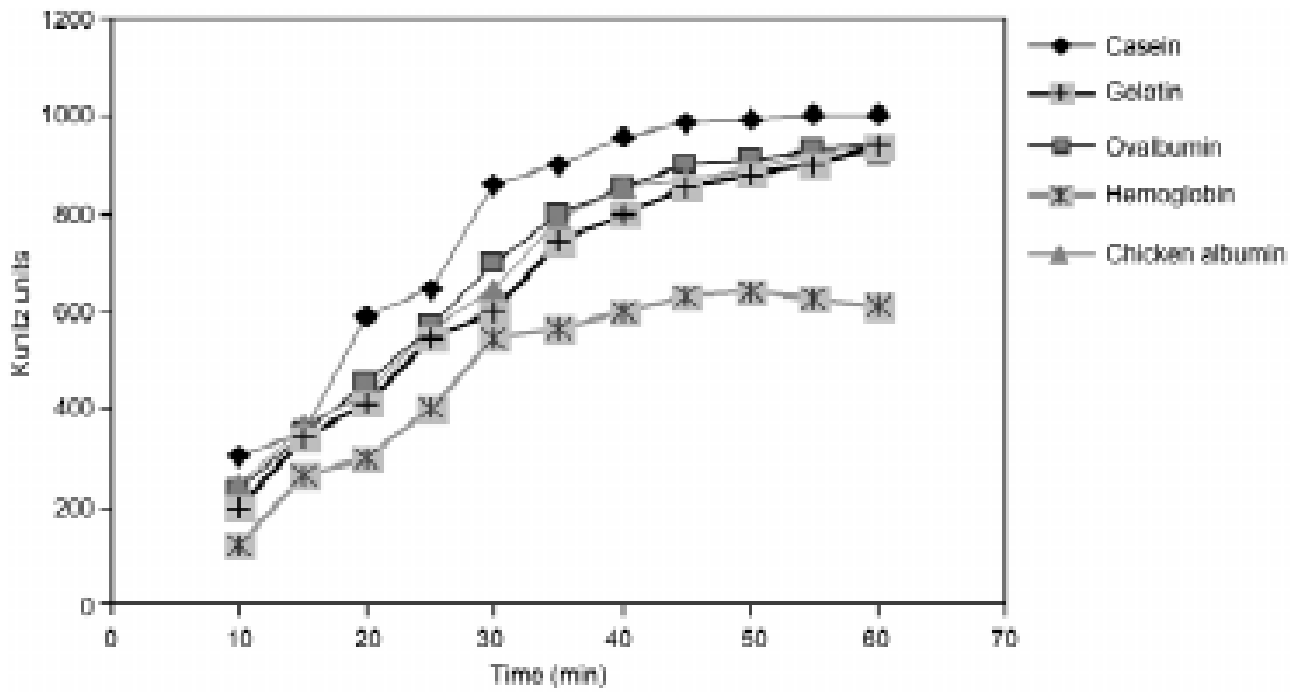

Fig. 4. Time course utilization of EAG-2 protease versus various natural substrates

ing 2 hour incubation. However, the activity reduced to $70 \%$ and $90 \%$ between $60-70^{\circ} \mathrm{C}$ (Fig. 3).

Enzyme performance in the presence of metals and inhibitors. The metals tested showed a variable effect. Calcium appeared as most active metal to trigger the proteolytic activity followed by zinc and barium, while a negative effect in terms of activity was observed with copper, nickel, magnesium and magnese. (Table II). Among inhibitors, PMSF appeared as most potent reducing enzyme activity down to $16 \%$ at $5 \mathrm{mM}$ conc. The null effect of EDTA on enzyme performance strengthens its relationship to serine type proteases.

Enzyme-substrate specificity. EAG-2 protease showed a broad substrate-activity relationship (Fig. 4). Rapid proteolysis was observed for first 40 minutes against all substrates tested except hemoglobin.

\section{Discussion}

Different purification procedures have been used to purify proteases (Bayoudh et al., 2000, Studdert et al., 2001; Yang et al., 2000). In this work a protease from Bacillus subtilis EAG-2 strain has been purified by using DEAE-Sepharose FF column to homogeneity. The enzyme exhibits a high specific activity at this stage with a purification yield of $29 \%$. It shows a single band of $27 \mathrm{KDa}$ on SDS gel which lies in the usual range $(15-36 \mathrm{KDa})$ of alkaline proteases from Bacillus strains (Wang et al., 2006; Singh et al., 2001a; Towatana et al., 1999). However, it showed two clear activity bands on zymogram gel which could be a distinguishing feature in addition to already known Bacillus subtilis proteases. It can be assumed that EAG-2 protease exists in a dimeric form in its native structure. 
Table II

Enzyme activity in the presence of active site inhibitors

\begin{tabular}{|l|c|}
\hline \multicolumn{1}{|c|}{ Compound (conc. 5 mM) } & Residual Activity \% \\
\hline Control & 100 \\
\hline Alcalase+PMSF & 10 \\
\hline Esperase+PMSF & 15 \\
\hline PMSF & 16 \\
\hline APMSF & 25 \\
\hline Iodoacetamide & 100 \\
\hline Leupeptin & 100 \\
\hline EGTA & 99.2 \\
\hline $\mathrm{EDTA}$ & 100 \\
\hline $\mathrm{CaCl}_{2}$ & 117 \\
\hline $\mathrm{MgCl}_{2}$ & 81 \\
\hline $\mathrm{CuCl}_{2}$ & 74 \\
\hline $\mathrm{BaCl}_{2}$ & 104 \\
\hline $\mathrm{NiCl}_{2}$ & 81 \\
\hline $\mathrm{NaCl}_{2}$ & 86 \\
\hline $\mathrm{FeCl}_{3}$ & 80 \\
\hline $\mathrm{CoCl}_{3}$ & 99.6 \\
\hline $\mathrm{ZnCl}_{2}$ & 78 \\
\hline $\mathrm{MnCl}_{2}$ & 78 \\
\hline
\end{tabular}

PMSF (Phenyl methane sulfonyl fluoride);

APMSF (Acetyl phenylmethane sulfonyl fluoride);

EDTA (Ethylenediaminetetracetic acid)

The optimum temperature range for proteases from Bacillus strains is $50-60^{\circ} \mathrm{C}$ (Adinarayana et al., 2003; Ferrero et al., 1996). The optimal temperature for EAG-2 protease was obtained at $65^{\circ} \mathrm{C}$ while it was found stable up to $90 \%$ for 60 minutes between 30 and $50^{\circ} \mathrm{C}$ comparable to earlier reports (Singh et al., 2001b), while the optimum working pH for EAG-2 protease is 8.5 which falls in rather moderate alkaline range. The stimulatory effect of metals like $\mathrm{Ca}^{+2}, \mathrm{Mg}^{+2}$ and $\mathrm{Mn}^{+2}$ on alkaline proteases have been previously reported but there was somewhat restricted activity in case of EAG-2 protease in the presence of $\mathrm{Mg}^{+2}$ and $\mathrm{Mn}^{+2}$. However, a boost in activity was found when co-incubated with calcium followed by zinc and barium. Inhibition studies provided an idea about the nature of the enzyme and its co-factor requirements. Most alkaline proteases from Bacillus strains are completely inhibited by PMSF (Beynon and Bond, 1989). The protease from Bacillus subtilis EAG-2 strain was also inhibited up to $84 \%$ and $75 \%$ of its original activity at $5 \mathrm{mM}$ conc. with PMSF and APMSF but it was not inhibited to any significant level by other inhibitors used in the study. Results shown in Fig. 4 describe its dynamic proteolytic behavior against various natural substrates. A continuous rise in catalysis rate was observed during first 30 minutes of incubation while afterwards it seemed to become saturated and hence resulted in a plateau phase in terms of activity. The enzyme worked in close relation with almost all substrates used in this study except hemoglobin. It might be due to a weak substrate binding because of less specific substrate pockets at the active catalytic sites for this particular substrate type. Thus it can be predicted from the present work that EAG-2 protease is a relatively new serine type protease that has prominent characteristics in term of activity and specificity. It might be a potential contribution to the existing protease family and especially to the emerging enzyme industry in Pakistan.

\section{Acknowledgements}

This work was financially supported by Higher Education Commission (Pakistan). A. Ghafoor says special thanks to Dr Joachim Shindler (Germany) for providing commercial proteases (Novo enzymes) used in this study.

\section{Literature}

Adinarayana K., P. Ellaiah and D.S., Prasad. 2003. Purification and partial characterization of thermostable serine alkaline protease from a newly isolated Bacillus subtilis PE-11. APPS Pharm. Sci. Technol. 4: 1-9.

Bayoudh A., N. Gharsallah, M. Chamkha, A. Dhouib, S. Ammar and M. Nasri. 2000. Purification and characterization of an alkaline protease from Pseudomonas aeruginosa MN1. J. Ind. Microbiol. Biotechnol. 24: 291-295.

Beynon R.J. and J.S. Bond. 1989. Proteolytic enzymes. IRL Press, Oxford.

Beg K.Q. and R. Gupta. 2003. Purification and characterization of an oxidation-stable, thiol-dependent serine alkaline protease from Bacillus mojavensis. Enzyme Microb. Technol. 32: 294-304. Chakrabarti S.K., N. Matsumura and R.S. Ranu. 2000. Purification and characterization of an extracellular alkaline serine protease from Aspergillus terreus (IJIRA 6.2). Curr. Microbiol. 40: 239-244.

Ferrero M.A., G.R. Castro, C.M. Abate, M.D. Bagion and F. Simeriz. 1996. Thermostable alkaline protease of Bacillus licheniformis MIR29: isolation, production and characterization. Appl. Microbiol. Biotechnol. 45: 327-332.

Ghafoor A. and S. Hasnain. 2009. Production dynamics of Bacillus subtilis strain AG-1 and EAG-2, producing moderately alkaline proteases. African J. Microbiol. Res. 3 (5): 258-263.

Kang M.S., B.K. Lim, I.S. Seong, J.H. Seol, N. Tanahashi, K. Tanaka and C.H. Chung. 2001. The ATP-dependent CodWX (HslVU) protease in Bacillus subtilis is an N-terminal serine protease. EMBO J. 20: 734-742.

Kim S.S., Y.J. Kim and I.K. Rhee. 2001. Purification and characterization of a novel extracellular protease from Bacillus cereus KCTC 3674. Arch. Microbiol. 175: 458-461.

Kobayashi T., Y. Hakamada, J. Hitomi, K. Koike and S. Ito. 1996. Purification of alkaline proteases from a Bacillus strain and their possible interrelationship. Appl. Microbiol. Biotechnol. 45: 63-71.

Kunitz M. 1947. Crystalline soybean trypsin inhibitor. Part II. General properties. J. Gen. Physiol. 30: 291-31.

Laemmli U.K. 1970. Cleavage of structural proteins during the assembly of the head of bacteriophage T4. Nature. 227: 680-685.

Rawlings N.D. and A.J. Barrett. 1993. Evolutionary families of peptidases. Biochem. J. 290: 205-218. 
Schmidt T.M., B. Bleakley and K.H. Nealson. 1988. Characterization of an extracellular protease from the insect pathogen Xenorhabdus luminescens. Appl. Environ. Microbiol. 54: 2793-2797. Singh J., N. Batra and R.C. Sobti. 2001a. Serine alkaline protease from newly isolated Bacillus sp. SSR1. Process Biochem. 36: 781-785.

Singh J., R.M. Vohra and D.K. Sahoo. 2001b Purification and characterization of two extracellular alkaline protease from a newly isolated obligate alkalophilic Bacillus sphaericus. J. Ind. Microbiol. Biotechnol. 26: 387-393.

Studdert C.A., M. K. Herrera Seitz, G. M. Plasencia, J.J. Sanchez and R.E. de Castro. 2001. Purification and biochemical characterization of the haloalkaliphilic archaeon Natronococcus occultus extracellular serine protease. J. Basic. Microbiol. 41: 375-383.
Takami H., T. Akiba and K. Horikoshi. 1989. Production of extremely thermostable alkaline protease from Bacillus sp. No.AH-101. Appl. Microbiol. Biotechnol. 30: 120-124.

Towatana N.H., A. Painupong and P. Suntinanalert. 1999. Purification and characterization of an extracellular protease from alkalophilic and thermophilic Bacillus sp. PS719. J. Biosci. Bioeng. 87: 581-587.

Wang C., B. Ji, B. Li and H. Ji. 2006. Enzymatic properties and identification of a fibrinolytic serine protease purified from Bacillus subtilis DC33. World J. Microbiol. Biotechnol. 22: 1365-1371.

Yang J., I. Shih, Y. Tzeng and S. Wang. 2000. Production and purification of protease from a Bacillus subtilis that can deproteinize crustacean wastes. Enzyme Microb. Technol. 26: 406-413. 